\title{
COMPARATIVE EFFICIENCY ANALYSIS OF HOSPITALS BASED ON THE REGION, OWNERSHIP, AND SERVICE USING DATA ENVELOPMENT ANALYSIS
}

\author{
Juyun Cho, Colorado State University-Pueblo, joey.cho@csupueblo.edu
}

\begin{abstract}
The health care industry is growing rapidly in the United States. Along with the growth, the way of reducing health care spending and improving the efficiency of the health care system has been discussed among researchers. In particular, hospital efficiency has been one of main topics in the health care industry. This paper employs a nonparametric approach to measure the efficiency of hospitals. Using a Data Envelopment Analysis model and publicly available data, the performance of hospitals in the United States is evaluated. The efficiency levels of the hospitals are compared and analyzed by considering different types of variables describing main characteristics of hospitals. The results of this study gives administrators not only an insight on their current efficiency rate and the ranking among the hospitals participated but also a way of changing their inefficiencies.
\end{abstract}

Keywords: Hospital efficiency, Data Envelopment Analysis (DEA), Decision Making Unit (DMU), Variable Returns to Scale (VRS)

\section{INTRODUCTION}

As our life expectancy is getting longer, living healthy life has become one of the most important discussion topics. Getting good health care services is considered critical to maintain a healthy life. As hospitals have been a central part of the health care services, finding and improving inefficiencies of hospitals can provide patients with better services and can lead to a huge reduction of health care spending.

Data Envelopment Analysis (DEA) was introduced by Charnes, Cooper, and Rhodes (1978) and was extended later by Banker, Charnes, and Cooper (1984). DEA has been used to measure efficiency of a set of peer entities called Decision Making Units (DMUs) such as hospitals, universities, and business firms, based on observational data. While several techniques such as stochastic frontier analysis and fixed effects regression models have been used to estimate an efficiency, DEA has been used as a preferred method for measuring hospital efficiency due to the following reasons. First, DEA is a nonparametric frontier method that uses linear programming to evaluate the relative technical efficiency of a DMU. Second, DEA can handle multiple inputs and outputs easily and is less vulnerable to the misspecification problems that can affect econometric models (Cordero et al, 2015). Third, DEA measures inputs and outputs in their natural units and does not require a functional form to be prescribed explicitly (Charnes, Cooper, Lewin, \& Seiford, 1994). Fourth, unlike statistical regressions that evaluates the average performance of multiple DMUs, DEA evaluates the performance of an individual DMU that compares each DMU with every other DMU in the sample (Cooper, Seiford, \& Zhu, 2011).

Since the first paper on the topic of DEA many papers have been published in a wide range of areas including the education sector (Abdullah, Tulus, Suwilo, Efendi, \& Mawengkang, 2018; Sagarra, Mar-Molinero, Agasisti, 2017; Thanassoulis et al, 2016), banks and mutual funds (Kai, Worthington, \& Zelenyuk, 2018; Nasseri, Ebrahimnejad, \& Gholami, 2018), public libraries (Guajardo, 2018; Park \& Rhee, 2016), regional welfare (Helmig \& Lapsley, 2001; Labaj, Luptacik, \& NeZinsky, 2014; Habibov \& Fan, 2010), environment (Martin-Gamboa, Iribarren, \& Dufour, 2018; Wang, Wei, \& Huang, 2018; Zhou, X. et al, 2018), local services (Guccio, Mignosa, \& Rizzo, 2018; Zhang, Tone, \& Lu, 2018), and the water sector (Emrouznejad, Paker, \& Tavres, 2008; Guajardo, 2015; Guerrini, Romano, Leardini, \& Martini, 2015).

DEA provides a lot of different models, and all DEA models can employ two orientations, input-oriented and outputoriented. Input-oriented models focus on minimizing input resources while trying to produce at least the given level of outputs. Whereas, output-oriented models attempt to produce maximum outputs with a given set of inputs. 


\section{Issues in Information Systems}

Volume 21, Issue 3, pp. 153-167, 2020

Depending on the DEA models, constant returns to scale (CRS) or variable returns to scale (VRS) method can be used. Constant returns to scale means an increase in inputs results in a proportional change in outputs. But in variable returns to scale, an increase in inputs is not reflected as a proportional change in outputs.

This study uses an input-oriented variable returns to scale (VRS) estimation model to assess the efficiency of hospitals in the United State. The efficiency scores are later combined and analyzed by seven geographic locations, ownership, and service types.

\section{LITERATURE REVIEW}

According to Emrouznejad and Yang (2018), health care including hospital is one of the most popular application areas in DEA along with energy, banking, and education. Sherman's doctoral dissertation in 1981 is considered as the first application of DEA in health care (Chilingerian \& Sherman, 2011). After that, Nunamaker (1983) and Sherman (1984) published the first and second DEA papers respectively in health care. Hollingsworth et al. (1999) was able to count 91 DEA studies in health care by 1997. In the later survey, Emrouznejad, Paker, and Tavres (2008) identified 103 journal papers using a keyword, health care or hospital.

In recent studies, various DEA models and input/output variables have been used to evaluate hospital efficiencies. Khushalani and Ozcan (2017) used dynamic network DEA to examine efficiency of hospitals between 2009 and 2013 using patients' visits, surgeries, and discharges. Omrani, Shafaat, and Emrouznejad (2018) used an integrated fuzzy clustering cooperative game DEA approach with application in hospital efficiency to investigate non homogenous DMUs. Miller, Wang, Zhu, Chen, and Hockenberry (2017) developed an integer-valued non-radial Russell DEA model to calculate and compare the efficiency of hospitals in Massachusetts and Connecticut pre- and post-health care reform. The inputs considered in Johannessen, Kittelsen, and Hagen (2017) were number of full-time equivalent physician, salary of physicians, nurses, secretaries, and other personnel. The outputs selected were number of patients treated by hospitalization, daycare treatment, total number of patient contacts, and outpatient treatment. Bahrami, Rafiei, Askari (2018) conducted a case study to assess economic, allocative, and technical efficiency in intensive care units of hospitals in Iran. They selected four input variables - number of physicians, nurses, active beds and equipment. Bed occupancy rate, the number of discharged patients, economic information such as bed price and physician's fee were selected as output variables. They found that the average scores of allocative, economic, technical, managerial, and scale efficiency were relatively high. Interestingly, Valdmanis, Rosko, Leleu, and Mukamel (2017) evaluated overall, technical, and scale efficiency on home health care agencies, which they believe play a vital role in the production of health. They found that home health care agencies, on average, could reduce inputs by $28 \%$ (overall efficiency), 23\% (technical efficiency), and 6\% (scale efficiency).

\section{RESEARCH METHODOLOGY}

This study employs an input-oriented Banker-Charnes-Cooper (BCC) DEA model known as a variable returns to scale (VRS) estimation model to assess an efficiency of hospitals located in the United States. Data were obtained from the annual survey of the American Hospital Association and contained observations for 10 variables on a total of 200 hospitals. These variables include geographic region, control, service, 4 inputs, and 3 outputs. The examples of other studies that have developed DEA frameworks for measuring hospital efficiency are considered when inputs and outputs are selected (Dyson et al, 2001; Tiemann \& Schreyögg, 2012). Table 1 shows a list of variables used in this study. 
Table 1. A List of Variables

\begin{tabular}{l|ll}
\hline \multicolumn{1}{c|}{ Type } & \multicolumn{1}{c}{ Description } \\
\hline Geographic region & 1. & South \\
& 2. & Southwest \\
& 3. & Northeast \\
& 4. & Northwest \\
& 5. & Midwest \\
& 6. & Rocky Mountain \\
& 7. & California \\
\hline Control & 1. & Government, Nonfederal \\
& 2. Nongovernment, Not-for-profit \\
& 3. For-profit \\
\hline Service & 4. & Federal government \\
\hline Inputs & 1. General Medical \\
& 2. Psychiatric \\
\hline Outputs & 1. Number of beds \\
& 2. Total amount of expenditures \\
& 3. Payroll \\
& 1. & Personnel \\
\hline
\end{tabular}

The variable of a geographic region contains 7 areas - South, Southwest, Northeast, Northwest, Midwest, Rocky Mountain, and California. The control variable represents the four types of ownership including 1) government, nonfederal, 2) nongovernment, not-for-profit, 3) for-profit, and 4) federal government. The service variable is the type of hospital, and two types of hospitals were used including 1) general medical and 2) psychiatric.

Four inputs and three outputs are utilized in this study. The first input variable is the number of beds (Beds), which is used as a proxy for material resources. The second and third input variable are the total amount of expenditures and payroll expenditures respectively. Both represent monetary inputs. The fourth input variable that represents a labor input is personnel including staffs, registered nurses, and doctors. The number of admissions, the number of outpatient's visits, and the number of births are used as outputs of hospital services.

As shown in figure 1, this study includes a two-stage process. In the first process, three input and two output variables are fed into a DEA model, and the efficiency measurements generated by DEA is analyzed in the second stage to see if there are any significant efficiency differences by geographic region, control, and service type. 


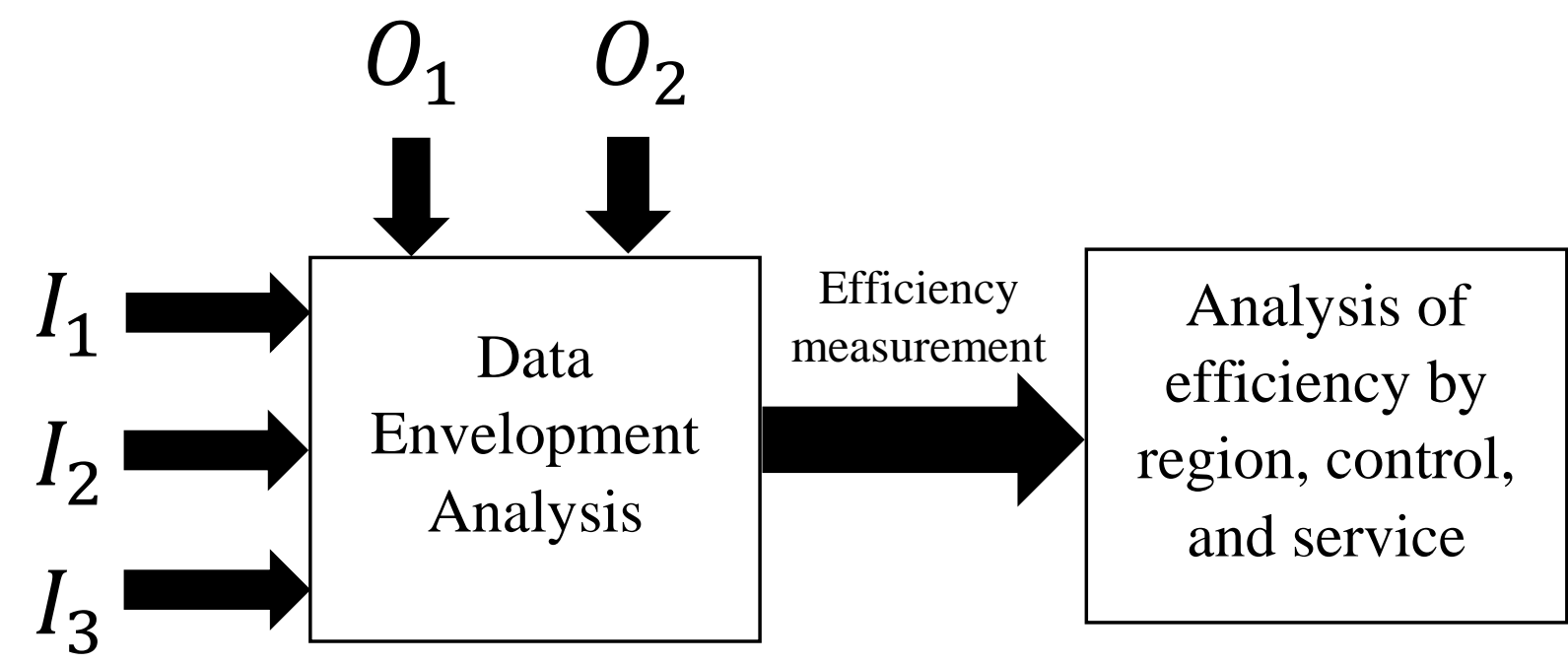

Figure 1. Two Stage Experiment Framework

\section{RESEARCH RESULTS AND DISCUSSIONS}

An input-oriented BCC model produces an ample amount of useful information. Table 2 shows a basic statistics on input and output data whereas table 3 gives correlation between data. The total expenditures and payroll expenditures are in units of $\$ 1,000$. Table 2 depicts that research data contains wide range of hospitals from a small hospital with 7 beds and 50 personnel to a large hospital with 1,297 beds and 4,087 personnel. In output statistics, a small hospital has only 111 admissions whereas a large hospital has 37,375 admissions. According to the table 3, a high correlation is noticed between three input variables including total expenditures, payroll expenditures, and personnel and an output variable, admission. This table also tells that an input variable Beds is not highly correlated with two output variables, Outpatient's Visits and Births. From the correlation between Total Expenditures and Payroll Expenditures, we can have a reasonable guess that payroll expenditures occupies a good portion of total expenditures.

Table 2. Descriptive Statistics on Inputs and Outputs

\begin{tabular}{lllllllll}
\hline \multirow{2}{*}{$\begin{array}{l}\text { Decision } \\
\text { Making Unit }\end{array}$} & Inputs & \multicolumn{9}{c}{ Outputs } \\
\cline { 2 - 3 } & Beds & Total Exp. & Payroll & Personnel & & Admission & Visit & Birth \\
\hline Mean & 209.9 & 67139.8 & 30500.9 & 861.5 & & 6831.8 & 98224 & 874 \\
St. Dev & 171.65 & 70210.30 & 32633.9 & 819.54 & & 6629.5 & 118567 & 1061 \\
Min & 7 & 2082 & 1053 & 50 & & 111 & 0 & 0 \\
Max & 1297 & 367706 & 188865 & 4087 & & 37375 & 813369 & 5699 \\
\hline
\end{tabular}




\section{Issues in Information Systems}

Volume 21, Issue 3, pp. 153-167, 2020

Table 3. A Correlation between Data

\begin{tabular}{lccccccc}
\hline & Beds & $\begin{array}{c}\text { Tot. } \\
\text { Exp. }\end{array}$ & $\begin{array}{c}\text { Payroll } \\
\text { Exp. }\end{array}$ & Personnel & Admissions & $\begin{array}{c}\text { Outpatient's } \\
\text { Visits }\end{array}$ & Births \\
\hline Beds & 1 & 0.71092 & 0.73658 & 0.75273 & 0.62487 & 0.34023 & 0.42888 \\
Tot. Exp. & 0.71092 & 1 & 0.98254 & 0.96471 & 0.90249 & 0.62942 & 0.71322 \\
Payroll Exp. & 0.73658 & 0.98254 & 1 & 0.95187 & 0.84821 & 0.62614 & 0.65958 \\
Personnel & 0.75273 & 0.96471 & 0.95187 & 1 & 0.87946 & 0.64402 & 0.69746 \\
Admissions & 0.62487 & 0.90249 & 0.84821 & 0.87946 & 1 & 0.60246 & 0.85562 \\
Outpatient’s & & & & & & & \\
Visits & 0.34023 & 0.62942 & 0.62614 & 0.64402 & 0.60246 & 1 & 0.56709 \\
Births & 0.42888 & 0.71322 & 0.65958 & 0.69746 & 0.85562 & 0.56709 & 1 \\
\hline
\end{tabular}

The values of efficiency scores range from 0.0 to 1.0. Any DMU that has a less than 1.0 is considered as inefficient DMU. Out of 200 hospitals, 30 hospitals are marked as efficient DMUs with an efficiency score of 1.0. 13 hospitals are ranked as the second best efficient hospitals with an efficiency score ranged from 0.901 to 0.9886 . This means the second group of hospitals are ranked as about $90 \%$ to $98 \%$ of the best group of hospitals. 23 hospitals are ranked in the third group with an efficiency score between 0.802 and 0.8931 . The rest of 123 hospitals are ranked under $80 \%$. The hospitals under $80 \%$ of efficiency have a lot of rooms to improve their efficiency compared to their peer hospitals as indicated later in this section. Table 4 shows the first 30 hospitals' efficiency score, rank, lambda value with reference DMUs, and the returns to scale (RTS) of a projected DMU. As an example, DMU \#5 has efficiency score of 0.5841 and ranks at $142^{\text {nd }}$. The efficiency score and rank are calculated using references (lambda) of the best three DMUs including \#6, \#21, and \#30. Along with the reference DMUs, distance numbers of $0.887,0.047$, and 0.024 show how far away DMU \#5 is from each reference DMU. The last column reveals the returns to scale. If output increases by less than the proportional change in inputs, there are decreasing returns to scale (DRS), whereas if output increases by more than the proportional changes in inputs, there are increasing returns to scale (IRS). Some of DMUs have constant returns to scale (CRS) meaning there is neither decreasing nor increasing returns to scale. 
Volume 21, Issue 3, pp. 153-167, 2020

Table 4. Efficiency Score, Rank, Reference, and RTS

\begin{tabular}{|c|c|c|c|c|c|c|c|c|c|}
\hline \multirow{2}{*}{$\begin{array}{l}\text { DMU } \\
1\end{array}$} & \multirow{2}{*}{$\begin{array}{l}\text { BCC } \\
\text { Efficiency } \\
\text { Score } \\
0.7167\end{array}$} & \multirow{2}{*}{$\begin{array}{l}\text { Rank } \\
93\end{array}$} & \multicolumn{3}{|c|}{ Reference(Lambda) } & \multirow[b]{2}{*}{0.122} & \multirow[b]{2}{*}{30} & \multirow[b]{2}{*}{0.663} & \multirow{2}{*}{$\begin{array}{l}\text { RTS of } \\
\text { Projected } \\
\text { DMU } \\
\text { Decreasing }\end{array}$} \\
\hline & & & 6 & 0.059 & 29 & & & & \\
\hline 2 & 0.7668 & 76 & 29 & 0.599 & 128 & 0.285 & 181 & 0.116 & Decreasing \\
\hline 3 & 0.9815 & 35 & 68 & 0.402 & 128 & 0.55 & 181 & 0.049 & Decreasing \\
\hline 4 & 0.8141 & 60 & 25 & 0.23 & 29 & 0.365 & 46 & 0.057 & Constant \\
\hline 5 & 0.5841 & 142 & 16 & 0.887 & 21 & 0.047 & 30 & 0.024 & Increasing \\
\hline 6 & 1 & 1 & 6 & 1 & & & & & Decreasing \\
\hline 7 & 0.7343 & 84 & 29 & 0.219 & 68 & 0.17 & 159 & 0.04 & Constant \\
\hline 8 & 0.5736 & 149 & 16 & 0.025 & 68 & 0.005 & 82 & 0.64 & Increasing \\
\hline 9 & 0.937 & 39 & 6 & 0.275 & 29 & 0.467 & 68 & 0.033 & Decreasing \\
\hline 10 & 0.8432 & 54 & 16 & 0.465 & 29 & 0.185 & 68 & 0.05 & Increasing \\
\hline 11 & 0.705 & 103 & 16 & 0.273 & 21 & 0.025 & 29 & 0.094 & Increasing \\
\hline 12 & 0.9612 & 38 & 16 & 0.489 & 29 & 0.133 & 30 & 0.16 & Increasing \\
\hline 13 & 0.5817 & 145 & 25 & 0.066 & 29 & 0.166 & 68 & 0.03 & Increasing \\
\hline 14 & 0.8388 & 56 & 29 & 0.282 & 30 & 0.598 & 48 & 0.052 & Decreasing \\
\hline 15 & 1 & 1 & 15 & 1 & & & & & Constant \\
\hline 16 & 1 & 1 & 16 & 1 & & & & & Increasing \\
\hline 17 & 1 & 1 & 17 & 1 & & & & & Constant \\
\hline 18 & 0.8199 & 58 & 29 & 0.093 & 30 & 0.319 & 48 & 0.166 & Decreasing \\
\hline 19 & 0.6 & 138 & 29 & 0.628 & 30 & 0.264 & 48 & 0.09 & Decreasing \\
\hline 20 & 0.2867 & 185 & 16 & 0.014 & 30 & 0.495 & 176 & 0.491 & Increasing \\
\hline 21 & 1 & 1 & 21 & 1 & & & & & Constant \\
\hline 22 & 0.7767 & 72 & 6 & 0.349 & 30 & 0.405 & 68 & 0.015 & Decreasing \\
\hline 23 & 0.619 & 131 & 6 & 0.037 & 30 & 0.566 & 68 & 0.023 & Decreasing \\
\hline 24 & 0.862 & 49 & 30 & 0.179 & 48 & 0.521 & 176 & 0.282 & Decreasing \\
\hline 25 & 1 & 1 & 25 & 1 & & & & & Constant \\
\hline 26 & 0.7164 & 94 & 6 & 0.097 & 29 & 0.207 & 30 & 0.657 & Decreasing \\
\hline 27 & 0.7976 & 67 & 29 & 0.183 & 30 & 0.73 & 68 & 0.025 & Constant \\
\hline 28 & 0.6703 & 115 & 6 & 0.14 & 30 & 0.645 & 48 & 0.193 & Decreasing \\
\hline 29 & 1 & 1 & 29 & 1 & & & & & Constant \\
\hline 30 & 1 & 1 & 30 & 1 & & & & & Constant \\
\hline 31 & 0.5441 & 158 & 6 & 0.166 & 29 & 0.111 & 30 & 0.584 & Decreasing \\
\hline 32 & 0.5815 & 146 & 15 & 0.086 & 16 & 0.597 & 30 & 0.317 & Increasing \\
\hline 33 & 0.9852 & 33 & 16 & 0.537 & 68 & 0.019 & 82 & 0.014 & Increasing \\
\hline 34 & 0.6246 & 129 & 6 & 0.51 & 30 & 0.118 & 181 & 0.373 & Decreasing \\
\hline 35 & 0.6378 & 126 & 6 & 0.436 & 30 & 0.441 & 128 & 0.022 & Decreasing \\
\hline 36 & 0.5692 & 151 & 29 & 0.783 & 128 & 0.196 & 181 & 0.021 & Decreasing \\
\hline 37 & 0.7197 & 90 & 16 & 0.07 & 82 & 0.167 & 108 & 0.511 & Increasing \\
\hline 38 & 0.5644 & 155 & 16 & 0.002 & 30 & 0.589 & 68 & 0.013 & Increasing \\
\hline
\end{tabular}


Figure 2 is another representation of efficiency scores of 200 hospitals as a bar chart to help visualize each DMU's efficiency.

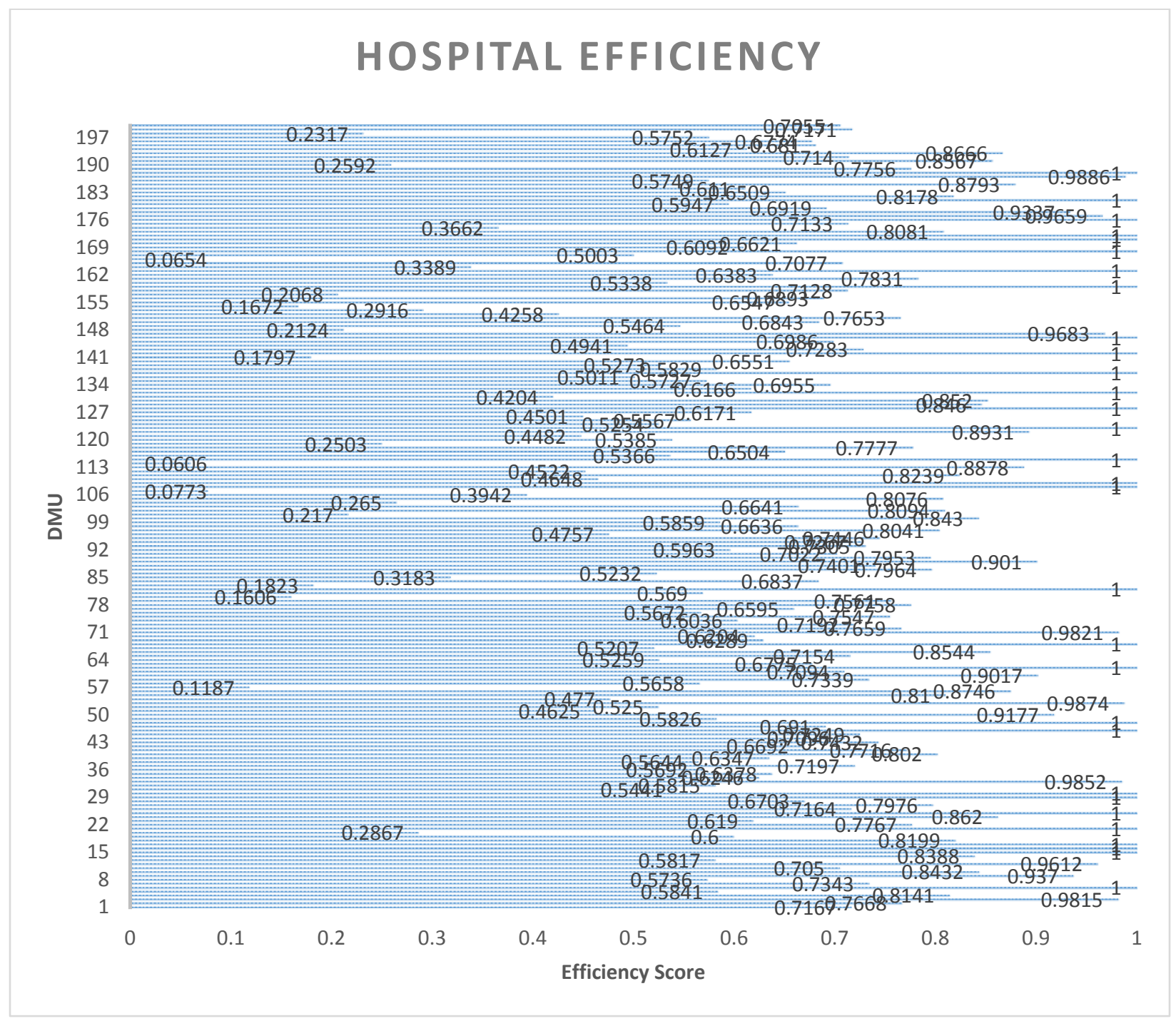

Figure 2. Hospital Efficiency Score Graph

As shown in table 5,17 hospitals are identified under less than $30 \%$ of maximum possible efficiency, and 14 hospitals are between 30 and $49.9 \%$ of a maximum efficiency. 103 hospitals $(31+34+38=103)$ occupy the middle section which ranges from $50.0 \%$ to $79.9 \%$ of a maximum efficiency. 36 hospitals $(23+13=36)$ are close to the full efficiency ranging between 80 and $99.9 \%$ of a maximum efficiency.

The second stage of the study is to analyze efficiency score by the geographical region, control, and service type to see if there is any difference. Figure 3 shows the average efficiency score of hospitals scattered in 7 geographical regions - South, Northeast, Midwest, Southwest, Rocky Mountain, California, and Northwest. Hospitals in California are ranked the top highest with the efficiency score of 0.817 , and hospitals in south and southwest area mark the 


\section{Issues in Information Systems}

Volume 21, Issue 3, pp. 153-167, 2020

second highest with the efficiency score of 0.769 and 0.75 respectively. Hospitals in Rocky Mountain are ranked right below these two regions with the efficiency of 0.744 . Hospitals in Northeast and Midwest are ranked bottom two with the efficiency of 0.628 and 0.611 respectively. The average efficiency between hospitals in California and in Midwest has a large gap of $20.6 \%$. To look at the efficiency of an individual DMU, the scattered plot of DMUs by geographical regions is illustrated in figure 4. In the figure 4, we can see that most hospitals in California are ranked above $80 \%$ whereas more than $70 \%$ of hospitals in Midwest are ranked below $60 \%$ of efficiency though there are 6 hospitals have a 1.0 efficiency score.

Table 5. Distribution of Efficiency Scores

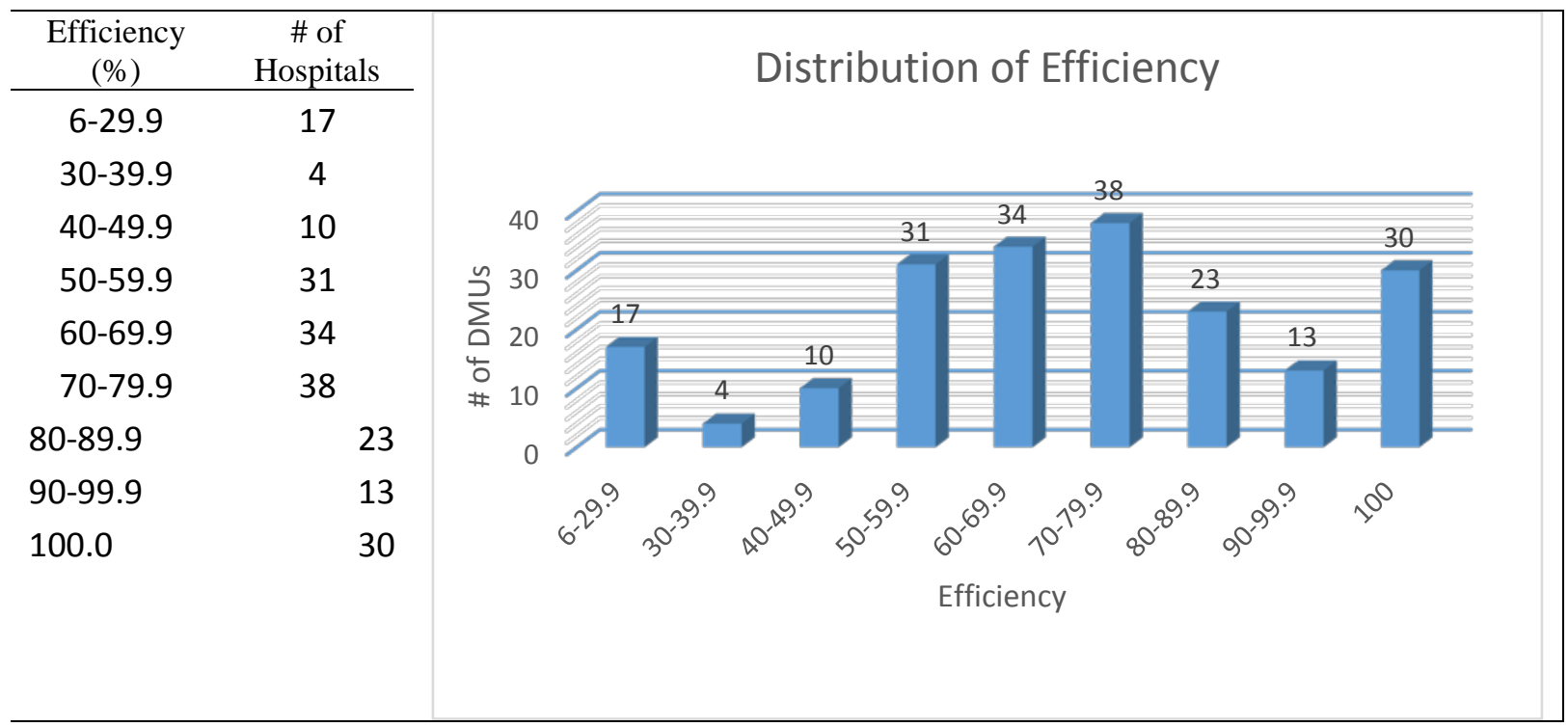

\section{Average Efficiency Score by Region}

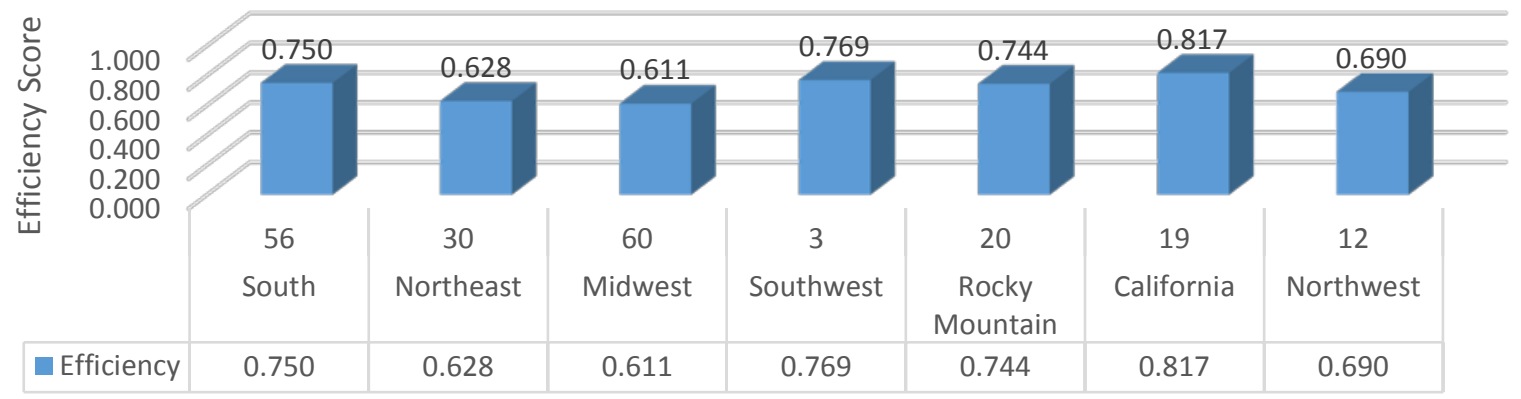

Geograpical Region 
Figure 3. Average Efficiency Score by Region

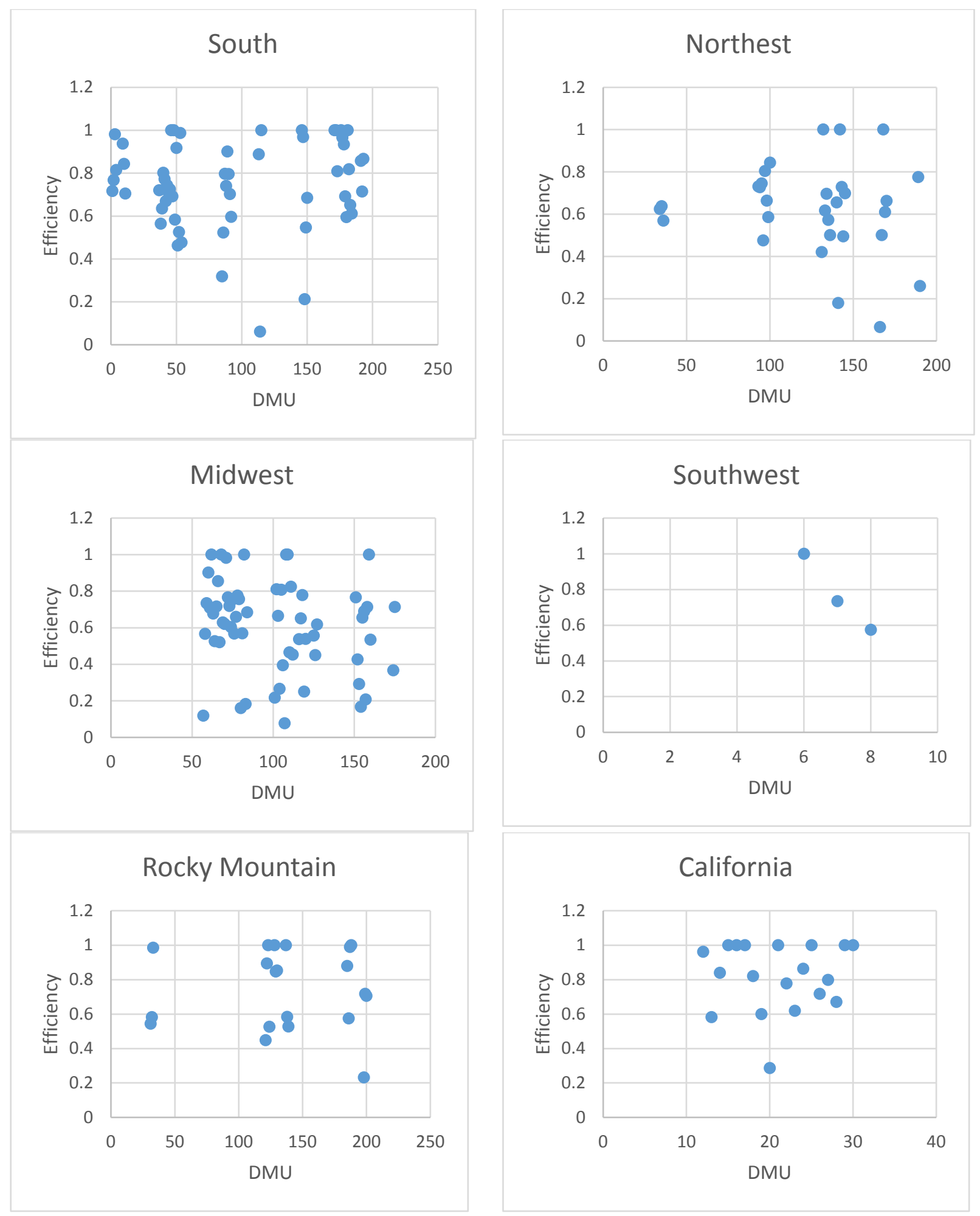




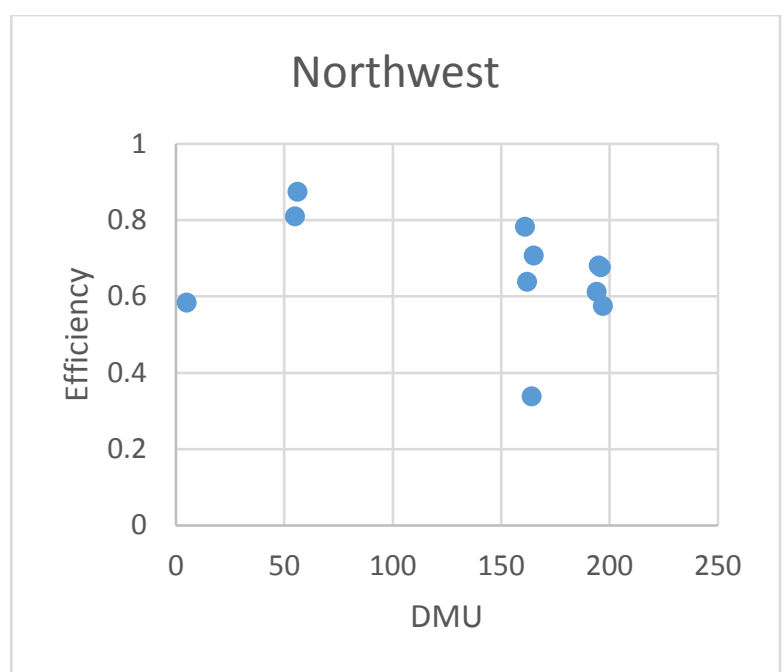

Figure 4. Scatter Plot of DMUs by Geographical Region (Continued)

Mean efficiency scores by ownership is shown in figure 5. This figure clearly shows that for-profit hospitals are operated most efficiently with a mean efficiency score 0.768 compared to other hospitals owned by government (nonfederal), nongovernment (not-for-profit), and federal government. Also, not-for-profit, nongovernment hospitals have the second highest mean efficiency score (0.717). Government, non-federal hospitals and federal government hospitals have a lowest mean DEA score of 0.613 and 0.610 respectively. The mean efficiency gap between for-profit hospitals and federal government owned hospitals is more than $15 \%$.

Average efficiency of two different types of hospitals is shown in figure 6. As shown in the figure, the general medical hospitals are more efficient than psychiatric hospitals by more than $21 \%$.

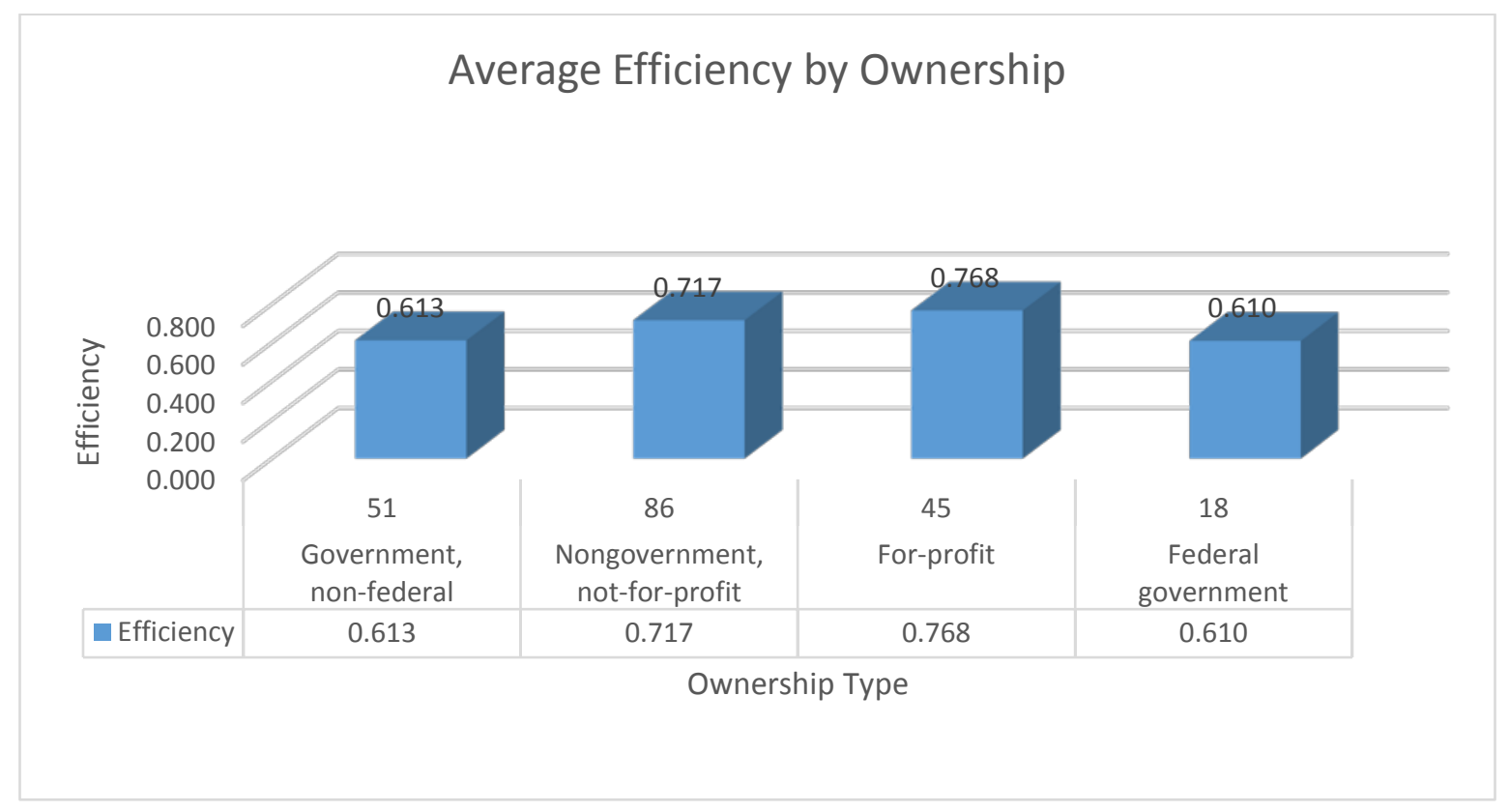

Figure 5. Average Efficiency Score by Ownership 


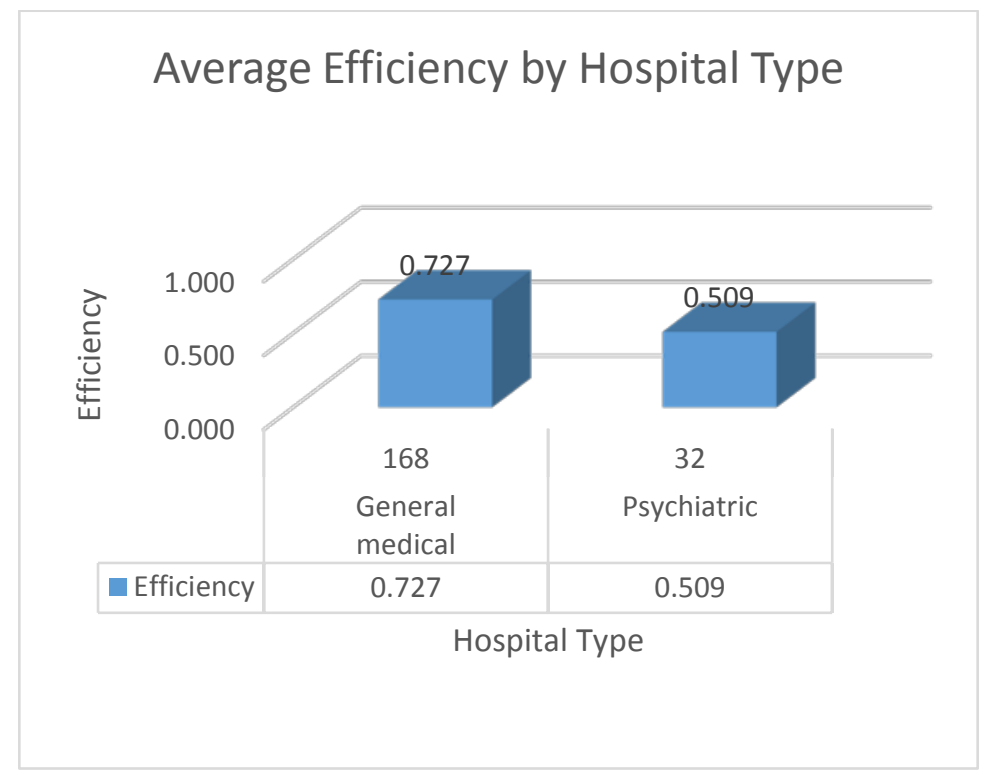

Figure 6. Average Efficiency Score by Control

Table 6 exhibits the projection of input variables. Total expenditures and payroll expenditures are in units of \$1,000. This table tells hospital administrators what they need to do to improve their inefficiencies. For example, DMU \#1 has an efficiency score of 0.7167 with 210 beds, total expenditures of \$56,831, payroll expenditures of \$22,061, and 792 employees. To lift the current efficiency to 1.0, or to be the best among the peer hospitals in the experiment, DMU $\# 1$ should 1 ) reduce the number of beds to 84.5 , which is $59.8 \%$ reduction, 2 ) reduce the total expenditures to $\$ 40,730$, which is $28.3 \%$ reduction, 3 ) reduce the payroll expenditures to $\$ 15,811$, which is $28.3 \%$ reduction, and 4 ) reduce the number of employees to 567.6, which is $28.3 \%$. Which actions administrators can take is depend on their situation, but the table 6 clearly displays where the inefficiency is and how to improve the efficiency for individual DMUs.

As shown in this section, some organizational factors such as geographic locations, the type of ownership of hospitals, and the service type of hospitals are compelling factors of efficiency. 
Table 6. Projection of Input Variables

\begin{tabular}{|c|c|c|c|c|c|c|c|c|c|c|c|c|c|}
\hline & & $\begin{array}{l}\mathrm{Be} \\
\text { ds }\end{array}$ & & & $\begin{array}{l}\text { Tot. } \\
\text { Exp. }\end{array}$ & & & $\begin{array}{l}\text { Payr } \\
\text { oll } \\
\text { Exp. }\end{array}$ & & & $\begin{array}{l}\text { Perso } \\
\text { nnel }\end{array}$ & & \\
\hline $\begin{array}{l}\mathrm{M} \\
\mathrm{U}\end{array}$ & $\begin{array}{l}\text { Scor } \\
\mathrm{e}\end{array}$ & $\begin{array}{l}\mathrm{Da} \\
\text { ta }\end{array}$ & $\begin{array}{l}\text { Projec } \\
\text { tion }\end{array}$ & $\begin{array}{l}\text { Diff.( } \\
\%)\end{array}$ & Data & $\begin{array}{l}\text { Projec } \\
\text { tion }\end{array}$ & $\begin{array}{l}\text { Diff.( } \\
\%)\end{array}$ & Data & $\begin{array}{l}\text { Projec } \\
\text { tion }\end{array}$ & $\begin{array}{l}\text { Diff.( } \\
\%)\end{array}$ & Data & $\begin{array}{l}\text { Projec } \\
\text { tion }\end{array}$ & $\begin{array}{l}\text { Diff.( } \\
\%)\end{array}$ \\
\hline & 0.71 & 21 & & & 5683 & 40730. & & 220 & 15811. & & & & \\
\hline 1 & 67 & 0 & 84.5 & -59.8 & 1 & 7 & -28.3 & 61 & 1 & -28.3 & 792 & 567.6 & -28.3 \\
\hline & 0.76 & 34 & & & 1272 & 97559. & & 557 & 42681. & & & & \\
\hline 2 & 68 & 7 & 252.8 & -27.2 & 23 & 7 & -23.3 & 99 & & -23.5 & 1762 & 1129.9 & -35.9 \\
\hline 3 & $\begin{array}{l}0.90 \\
15 \\
0.81\end{array}$ & $\begin{array}{l}51 \\
1 \\
14\end{array}$ & 398.2 & -22.1 & $\begin{array}{l}93 \\
2446\end{array}$ & $\begin{array}{l}7 \\
19915 .\end{array}$ & -4.1 & $\begin{array}{l}26 \\
105\end{array}$ & $\begin{array}{l}50191 . \\
8550.9\end{array}$ & -1.9 & 2310 & 1991.2 & -13.8 \\
\hline 4 & $\begin{array}{l}41 \\
0.58\end{array}$ & 2 & 75.9 & -46.6 & $\begin{array}{l}2 \\
1373\end{array}$ & 5 & -18.6 & $\begin{array}{l}03 \\
636\end{array}$ & $\begin{array}{l}1 \\
3237.5\end{array}$ & -18.6 & 328 & 267.0 & -18.6 \\
\hline 5 & 41 & $\begin{array}{l}40 \\
22\end{array}$ & 23.4 & -41.6 & $\begin{array}{l}0 \\
9325\end{array}$ & $\begin{array}{l}6617.4 \\
93256 .\end{array}$ & -51.8 & $\begin{array}{l}8 \\
339\end{array}$ & 1 & -49.2 & 181 & 105.7 & -41.6 \\
\hline 6 & $\begin{array}{l}1 \\
0.73\end{array}$ & $\begin{array}{l}0 \\
13\end{array}$ & 220.0 & 0.0 & $\begin{array}{l}7 \\
4545\end{array}$ & $\begin{array}{l}9 \\
33378 .\end{array}$ & 0.0 & $\begin{array}{l}20 \\
269\end{array}$ & $\begin{array}{l}33920 \\
14496 .\end{array}$ & 0.0 & 1077 & 1077.0 & 0.0 \\
\hline 7 & $\begin{array}{l}43 \\
0.57\end{array}$ & 7 & 73.5 & -46.4 & 8 & $\begin{array}{l}7 \\
3363.5\end{array}$ & -26.6 & $\begin{array}{l}19 \\
276\end{array}$ & $\begin{array}{l}1 \\
1587.7\end{array}$ & -46.1 & 742 & 544.8 & -26.6 \\
\hline 8 & $\begin{array}{l}36 \\
0.93\end{array}$ & $\begin{array}{l}80 \\
44\end{array}$ & 45.9 & -42.6 & $\begin{array}{l}6151 \\
9899\end{array}$ & $\begin{array}{l}4 \\
92758 .\end{array}$ & -45.3 & $\begin{array}{l}8 \\
409\end{array}$ & $\begin{array}{l}3 \\
38377 .\end{array}$ & -42.6 & 131 & 74.3 & -43.3 \\
\hline 9 & $\begin{array}{l}7 \\
0.84\end{array}$ & 0 & 250.7 & -43.0 & $\begin{array}{l}2 \\
1156\end{array}$ & $\begin{array}{l}7 \\
9755.1\end{array}$ & -6.3 & $\begin{array}{l}56 \\
566\end{array}$ & $\begin{array}{l}1 \\
4513.4\end{array}$ & -6.3 & 1594 & 1089.9 & -31.6 \\
\hline 10 & $\begin{array}{l}32 \\
0.70\end{array}$ & 48 & 40.5 & -15.7 & $\begin{array}{l}9 \\
1135\end{array}$ & $\begin{array}{l}8 \\
8006.3\end{array}$ & -15.7 & $\begin{array}{l}4 \\
508\end{array}$ & 8 & -20.3 & 233 & 193.2 & -17.1 \\
\hline 11 & $\begin{array}{l}5 \\
0.96\end{array}$ & 56 & 39.5 & -29.5 & $\begin{array}{l}6 \\
1520\end{array}$ & $\begin{array}{l}7 \\
14610 .\end{array}$ & -29.5 & $\begin{array}{l}4 \\
708\end{array}$ & 3584.4 & -29.5 & 241 & 147.8 & -38.7 \\
\hline 12 & $\begin{array}{l}12 \\
0.58\end{array}$ & $\begin{array}{l}46 \\
10\end{array}$ & 44.2 & -3.9 & $\begin{array}{l}0 \\
2084\end{array}$ & $\begin{array}{l}2 \\
12126 .\end{array}$ & -3.9 & $\begin{array}{l}5 \\
970\end{array}$ & $\begin{array}{l}6810.1 \\
5647.2\end{array}$ & -3.9 & 203 & 195.1 & -3.9 \\
\hline 13 & $\begin{array}{l}17 \\
0.83\end{array}$ & $\begin{array}{l}9 \\
30\end{array}$ & 63.4 & -41.8 & $\begin{array}{l}8 \\
6277\end{array}$ & $\begin{array}{l}2 \\
52656 .\end{array}$ & -41.8 & $\begin{array}{l}9 \\
289\end{array}$ & $\begin{array}{l}4 \\
22683 .\end{array}$ & -41.8 & 325 & 189.0 & -41.8 \\
\hline 14 & 88 & 6 & 131.3 & -57.1 & $\begin{array}{l}8 \\
2030\end{array}$ & 6 & -16.1 & $\begin{array}{l}58 \\
123\end{array}$ & 7 & -21.7 & 676 & 567.0 & -16.1 \\
\hline 15 & 1 & 7 & 7.0 & 0.0 & 0 & $\begin{array}{l}20300 \\
3835.9\end{array}$ & 0.0 & $\begin{array}{l}00 \\
201\end{array}$ & $\begin{array}{l}12300 \\
2014.9\end{array}$ & 0.0 & 347 & 347.0 & 0.0 \\
\hline 16 & 1 & $\begin{array}{l}16 \\
16\end{array}$ & 16.0 & 0.0 & $\begin{array}{l}3836 \\
4141\end{array}$ & 7 & 0.0 & $\begin{array}{l}5 \\
206\end{array}$ & 9 & 0.0 & 79 & 79.0 & 0.0 \\
\hline 17 & $\begin{array}{l}1 \\
0.81\end{array}$ & $\begin{array}{l}7 \\
44\end{array}$ & 167.0 & 0.0 & $\begin{array}{l}7 \\
1449\end{array}$ & $\begin{array}{l}41417 \\
11885\end{array}$ & 0.0 & $\begin{array}{l}33 \\
616\end{array}$ & 20633 & 0.0 & 505 & 505.0 & 0.0 \\
\hline 18 & 99 & $\begin{array}{l}4 \\
23\end{array}$ & 298.2 & -32.8 & $\begin{array}{l}66 \\
6799\end{array}$ & $\begin{array}{l}8 \\
40797 .\end{array}$ & -18.0 & $\begin{array}{l}67 \\
312\end{array}$ & $\begin{array}{l}50561 \\
18770 .\end{array}$ & -18.0 & 1543 & 1265.1 & -18.0 \\
\hline 19 & $\begin{array}{l}0.6 \\
0.28\end{array}$ & $\begin{array}{l}6 \\
24\end{array}$ & 110.9 & -53.0 & $\begin{array}{l}7 \\
1231\end{array}$ & 6 & -40.0 & $\begin{array}{l}85 \\
418\end{array}$ & 7 & -40.0 & 755 & 453.0 & -40.0 \\
\hline 20 & 67 & 7 & 70.8 & -71.3 & $\begin{array}{l}75 \\
2831\end{array}$ & 26330 & -78.6 & $\begin{array}{l}99 \\
125\end{array}$ & 11757 & -71.9 & 959 & 275.0 & -71.3 \\
\hline 21 & $\begin{array}{l}1 \\
0.77\end{array}$ & $\begin{array}{l}93 \\
23\end{array}$ & 93.0 & 0.0 & $\begin{array}{l}8 \\
8808\end{array}$ & $\begin{array}{l}28318 \\
68318 .\end{array}$ & 0.0 & $\begin{array}{l}89 \\
321\end{array}$ & $\begin{array}{l}12589 \\
25001\end{array}$ & 0.0 & 325 & 325.0 & 0.0 \\
\hline 22 & 67 & 6 & 171.3 & -27.4 & 0 & 3 & -22.4 & 91 & 9 & -22.3 & 954 & 740.9 & -22.3 \\
\hline
\end{tabular}


Table 6. Projection of Input Variables

\begin{tabular}{|c|c|c|c|c|c|c|c|c|c|c|c|c|c|}
\hline & & $\begin{array}{l}\text { Be } \\
\text { ds }\end{array}$ & & & $\begin{array}{l}\text { Tot. } \\
\text { Exp. }\end{array}$ & & & $\begin{array}{l}\text { Payr } \\
\text { oll } \\
\text { Exp. }\end{array}$ & & & $\begin{array}{l}\text { Perso } \\
\text { nnel }\end{array}$ & & \\
\hline $\begin{array}{l}\mathrm{M} \\
\mathrm{U}\end{array}$ & $\begin{array}{l}\text { Sco } \\
\text { re }\end{array}$ & $\begin{array}{l}\mathrm{Da} \\
\text { ta }\end{array}$ & $\begin{array}{l}\text { Projec } \\
\text { tion }\end{array}$ & $\begin{array}{l}\text { Diff.( } \\
\%)\end{array}$ & Data & $\begin{array}{l}\text { Projec } \\
\text { tion }\end{array}$ & $\begin{array}{l}\text { Diff.( } \\
\%)\end{array}$ & Data & $\begin{array}{l}\text { Projec } \\
\text { tion }\end{array}$ & $\begin{array}{l}\text { Diff.( } \\
\%)\end{array}$ & Data & $\begin{array}{l}\text { Projec } \\
\text { tion }\end{array}$ & $\begin{array}{l}\text { Diff.( } \\
\%)\end{array}$ \\
\hline & 0.6 & 22 & & & 1073 & 61878. & & 386 & 23936. & & & & \\
\hline 23 & $\begin{array}{l}19 \\
0.8\end{array}$ & $\begin{array}{l}0 \\
22\end{array}$ & 136.2 & -38.1 & $\begin{array}{l}13 \\
1164\end{array}$ & $\begin{array}{l}3 \\
70086 .\end{array}$ & -42.3 & $\begin{array}{l}68 \\
490\end{array}$ & $\begin{array}{l}1 \\
30851 .\end{array}$ & -38.1 & 1091 & 675.3 & -38.1 \\
\hline 24 & 62 & 8 & 196.5 & -13.8 & $\begin{array}{l}86 \\
2062\end{array}$ & 5 & -39.8 & $\begin{array}{l}17 \\
300\end{array}$ & 4 & -37.1 & 671 & 578.4 & -13.8 \\
\hline 25 & 1 & 83 & 83.0 & 0.0 & 5 & 20625 & 0.0 & 9 & 3009 & 0.0 & 300 & 300.0 & 0.0 \\
\hline
\end{tabular}

\section{CONCLUSION}

This study analyzes the efficiency of hospitals in the United States by using a BCC DEA model known as a variable returns to scale estimation. Further, the efficiency scores generated by the DEA model are classified and examined by seven geographical locations, four types of ownership, and finally, two types of service. Hospitals in California are standout among the seven regions and the for-profit hospitals have a better efficiency than the not-for-profit hospitals, government owned hospitals (non-federal), and federal owned hospitals. Comparison between general medical hospitals and psychiatric hospitals shows that the general medical hospitals outperform the other.

The main contribution of this study can be summarized as follows. First, the presented efficiency scores of hospitals give administrators not only an insight on their current hospital's efficiency rate and the ranking among the peer hospitals under consideration but also a way of improving their inefficiencies. Second, research results can help administrators set target hospitals for benchmarking and identify the performance gap between their hospitals and the best hospitals. Third, the analysis of hospital efficiency by region, ownership, and service gives an overview on how main characteristics of hospitals play a role in efficiencies.

Future research efforts might include an artificial neural network (ANN) combining with a DEA model to have a capability of prediction. Also, experiments with a larger data set will definitely enhance our understanding on the subject matter.

\section{REFERENCES}

Abdullah, D., Tulus, S., Suwilo, S., Efendi, M., \& Mawengkang, H. (2018). A research framework for data envelopment analysis with upper bound on output to measure efficiency performance of higher learning institution in Aceh province. International Journal of Advanced Science, Engineering and Information Technology. 8(2), 336-341.

Bahrami, M. A., Rafiei, S., \& Askari, R. (2018). Data envelopment analysis for estimating efficiency of intensive care units: a case study in Iran. International Journal of Health Care Quality Assurance, 31(4), 276-282.

Banker, R. D., Charnes, A. \& Cooper, W. W. (1984). Some models for estimating technical and scale inefficiencies in data envelopment analysis. Management Science, 3(9), 1078-1092.

Charnes, A., Cooper, W. W., \& Rhodes, E. (1978). Measuring the efficiency of decision making units. European Journal of Operational Research, 2(6), 429-444.

Charnes, A., Cooper, W. W., Lewin, A. Y., \& Seiford, L. M. (1994). Basic DEA models, data envelopment analysis: Theory, methodology, and application. Boston: Kluwer Academic Publisher. 
Chilingerian, J. A., \& Sherman, H. D. (2011). Health-care application: From hospitals to physicians, from productive efficiency to quality frontiers. In Cooper, W. W., Seiford L., \& Zhu, J. (Eds.), Handbook on data envelopment analysis ( $2^{\text {nd }}$ ed.). (pp. 445-493). New York: Springer.

Cooper, W. W., Seiford, L. M., \& Zhu, J. (2011). Handbook on data envelopment analysis. New York: Springer.

Cordero, J. M., Alonso-Morán, E., Nuño-Solinis, R., Orueta, J. F., \& Arce, R. S. (2015). Efficiency assessment of primary care providers: A conditional nonparametric approach. European Journal of Operational Research, 240, 235-244.

Dyson, R, G., Allen, R., Camanho, A. S., Podinovski, V. V., Sarrico, C. C., \& Sale, E. A. (2001). Pitfalls and protocols in DEA. European Journal of Operational Research, 132, 245-259.

Emrouznejad, A., \& Yang, G. (2018). A survey and analysis of the first 40 years of scholarly literature in DEA: 1978-2016. Socio-Economic Planning Sciences, 61, 4-8.

Emrouznejad, A., Parker, B. R., \& Tavres, G. (2008). Evaluation of research in efficiency and productivity: A survey and analysis of the first 30 years of scholarly literature in DEA: 1978-2016. Socio-Economic Planning Sciences, 42(3), 151-157.

Guajardo, S. A. (2015). Assessing organizational efficiency and workforce diversity: An application of data envelopment analysis to New York City Agencies. Public Personnel Management, 44(2), 239-265.

Guajardo, S. A. (2018). Special district libraries and operating costs: An application of data envelopment analysis with discretionary and non-discretionary inputs. Journal of Library Administration, 58(3), 241-263.

Guccio, C., Mignosa, A., \& Rizzo, I. (2018). Are public state libraries efficiency? An empirical assessment using network data envelopment analysis. Socio-Economic Panning Sciences, doi: 10.1016/j.seps.2018.01.00.

Guerrini, A., Romano, G., Leardini, C., \& Martini, M. (2015). Measuring the efficiency of wastewater services through data envelopment analysis. Water Science \& Technology, 71(12), 1845-1851.

Habibov, N. N., \& Fan, L. (2010). Comparing and contrasting poverty reduction performance of social welfare programs across jurisdictions in Canada using data envelopment analysis: An exploratory study of the era of devolution. Evaluation and Program Planning, 33(4), 457-467.

Helmig, B., \& Lapsley, I. (2001). On the efficiency of public, welfare and private hospitals in Geremany over time: A sectoral data envelopment analysis study. Health Services Management Research, 14(4). 263-274.

Hollingsworth, B., Dawson, P. J., Maniadakis, N. (1999). Efficiency measurement of health care: A review of nonparametric methods and applications. Health Care Manage Science, 2(3), 161-72.

Johannessen, K. A., Kittelsen, S. A. C., \& Hagen, T. (2017). Assessing physician productivity following Norwegian hospital reform: A panel and data envelopment analysis. Social Science \& Medicine 175, 117-126. https://doi.org/10.1016/j.socscimed.2017.01.008

Kai, D., Worthington, A. C., \& Zelenyuk, V. (2018). Data envelopment analysis, truncated regression and doublebootstrap for panel data with application to Chinese banking. European Journal of Operational Research, 265(2), 748-764.

Khushalani, J., \& Ozcan, Y. A. (2017). Are hospitals producing quality care efficiently? An analysis using dynamic network data envelopment analysis (DEA). Socio-Economic Planning Sciences, 60, 15-23. https://doi.org/10.1016/j.seps.2017.01.009

Labaj, M., Luptacik, M., \& NeZinsky, E. (2014). Data envelopment analysis for measuring economic growth in terms of welfare beyond GDP. Emperica, 41(3), 407-424. 


\section{Issues in Information Systems}

Volume 21, Issue 3, pp. 153-167, 2020

Martin-Gamboa, M., Iribarren, D., \& Dufour, J. (2018). Environmental impact efficiency of natural gas combined cycle power plants: A combined life cycle assessment and dynamic data envelopment analysis approach. Science of The Total Environment, 615, 29-27.

Miller, F., Wang, J., Zhu, J., Chen, Y., \& Hockenberry, J. (2017). Investigation of the impact of the Massachusetts health care reform on hospital costs and quality of care. Annals of Operations Research, 250(1), 129-146.

Nasseri, S. H., Ebrahimnejad, A., \& Gholami, O. (2018). Fuzzy stochastic data envelopment analysis with undesirable outputs and its application to banking industry. International Journal of Fuzzy Systems, 20(2), 534548.

Nunamaker, T. (1983). Measuring routine nursing service efficiency: a comparison of cost per day and data envelopment analysis models. Health Services Research, 18(2 Pt 1), 183-205.

Omrani, H., Shafaat, K., Emrouznejad, A. (2018). An integrated fuzzy clustering cooperative game data envelopment analysis model with application in hospital efficiency. Expert Systems with Applications 114, 615-628. https://doi.org/10.1016/j.eswa.2018.07.074

Park, H., \& Rhee, H. (2016). A study on the operational efficiency analysis of university libraries. Journal of the Korean Society for Information Management, 33(1), 139-160.

Sagarra, M., Mar-Molinero, C., \& Agasisti, T. (2017). Exploring the efficiency of Mexican universities: Integrating data envelopment analysis and multidimensional scaling. Omega, 67, 123-133.

Sherman, H. D. (1984). Hospital efficiency measurement and evaluation. Med Care. 22(10), 922-928.

Thanassoulis, E., De Witte, K., Johnes, J., Johnes, G., Karagiannis, G., \& Portela, C. S. (2016). Applications of data envelope analysis in education. In: J. Zhu (Ed.). Data envelopment analysis. International Series in Operations Research \& Management Science, 238, Boston: Springer

Tiemann, O. \& Schreyogg, J. (2012). Changes in hospital efficiency after privatization. Health Care Management Science, 15(4), 310-326.

Valdmanis, V. G., Rosko, M. D., Leleu, H., \& Mukamel, D. (2017). Assessing overall, technical, and scale efficiency among home health care agencies. Health Care Management Science, 20(2), 265-275.

Wang, K., Wei, Y. \& Huang, Z. (2018). Environmental efficiency and abatement efficiency measurements of China's thermal power industry: A data envelopment analysis based material balance approach. European Journal of Operational Research, 269(1), 35-50.

Zhang, X., Tone, K., \& Lu, Y. (2018). Impact of the local public hospital reform on the efficiency of medium-sized hospitals in Japan: An improved slack-based measure data envelopment analysis. Health Services Research, 53(2), 896-918.

Zhou, X., Xu, Z., Yao, L., Tu, Y., Lev, B., \& Pdrycz, W. (2018). A novel data envelopment analysis model for evaluating industrial production and environmental management system. Journal of Cleaner Production, 170, 773-788. 